\title{
The effects of nitroglycerin in the zone of stasis in a rat burn model
}

\author{
Metin Gündüz, M.D., ${ }^{1} \odot$ Tamer Sekmenli, M.D., ${ }^{1}$ \\ Ceyhan Uğurluoğlu, M.D., ${ }^{2}$ i İlhan Çiftçi, M.D. ${ }^{1}$
}

${ }^{1}$ Department of Pediatric Surgery, Selçuk University Faculty of Medicine, Konya-Turkey

${ }^{2}$ Department of Pathology, Selçuk University Faculty of Medicine, Konya-Turkey

\begin{abstract}
BACKGROUND: Studies evaluating the recovery of the zone of stasis is an important issue in burn research. In this study, we aimed to evaluate and compare the efficiency of an anti-ischemic and vasodilatory agent, a topical agent containing $2 \%$ nitroglycerin with $1 \%$ silver sulfadiazine, and bacitracin-neomycin sulfate in the zone of stasis histomorphologically and immunohistochemically.

METHODS: We conducted an experimental study using 30 Wistar-Albino rats, each weighing 250-300 grams. The rats were divided randomly into five groups (six rats in each group). In this study, the "comb model," which was deemed to be the most appropriate experimental model to produce an injury with predictable zones and was first described by Regas and Erhlich, was used. The following were applied to the zone of stasis after creating a burn model in 0,24 , and 48 hours: topical $2 \%$ nitroglycerin, I\% silver sulfadiazine, bacitracin-neomycin sulfate, and Vaseline-lanolin (sham). After 72 hours, biopsies were performed from the zone of stasis and evaluated by histomorphological and immunohistochemical CD 34 (expressed in human endothelial and hematopoietic cells) and D 2-40 (expressed in the endothelium of lymphatic capillaries) methods. The results were evaluated using the chi-square test.
\end{abstract}

RESULTS: Compared with the other groups, a statistically significant difference was found in edema, inflammation, and vascular proliferation in the nitroglycerin group. Significantly more intense staining for CD 34 was found in the nitroglycerin group compared with the other groups. Immunohistochemical staining for D 2-40 was also found statistically significant in the nitroglycerin group $(p<0.05)$.

CONCLUSION: A topical containing $2 \%$ nitroglycerin increases vascular proliferation in the zone of stasis affects the recovery and may be used as a new agent in burn injury treatment.

Keywords: Burn injury; nitroglycerin; the zone of stasis.

\section{INTRODUCTION}

Studies evaluating the recovery of the zone of stasis are an important issue in burn research. According to Jackson's model, based on the severity of thermal injury destruction and blood flow alterations, three distinct zones of tissue injury are known..$^{[1]}$ The zone of coagulation is at the center of the wound without living tissue. Altough the zone of stasis is ischemic due to capillary vasoconstruction, it is vital. The outer periphery of the burn wound is the zone of hyperemia, with increased blood perfusion mediated by local inflammatory responses. ${ }^{[2]}$ The tissue in this zone usually re- covers completely unless complicated by infection or severe hypoperfusion. In the zone of stasis, blood flow is impaired on the first day of the burn, and the depth of burn necrosis might be decreased by preventing progressive capillary stasis in the early post-burn hours. ${ }^{[3,4]}$ The most common topical agents being used in wound care for burned patients to delay wound colonization are $1 \%$ silver sulfadiazine and bacitracin neomycin pomade. ${ }^{[5]} \mathrm{A}$ topical agent containing $2 \%$ nitroglycerin induces a local vasodilatory response in dermal vessels. ${ }^{[6,7]}$ In the present study, we aimed to evaluate and compare the efficiency of an anti-ischemic and vasodilatory agent, a topical agent containing $2 \%$ nitroglycerin with I $\%$ silver sulfa-

Cite this article as: Gündüz M, Sekmenli T, Uğurluoğlu C, Çiftçi İ. The effects of nitroglycerin in the zone of stasis in a rat burn model. Ulus Travma Acil Cerrahi Derg 2020;26:171-177.

Address for correspondence: Metin Gündüz, M.D.

Selçuk Üniversitesi Tıp Fakültesi, Çocuk Cerrahisi Anabilim Dalı, 42।3। Konya, Turkey

Tel: +90 332 - 24l $2181 \quad$ E-mail: drmetingunduz@yahoo.com

Ulus Travma Acil Cerrahi Derg 2020;26(2):17I-177 DOI: 10.14744/tjtes.2019.00005 Submitted: 10.05.2018 Accepted: 04.02.2019 Online: 24.02.2020

Copyright 2020 Turkish Association of Trauma and Emergency Surgery 
diazine, and bacitracin-neomycin sulfate in the zone of stasis histomorphologically and immunohistochemically. We anticipated the anti-ischemic and vasodilatory effects of $2 \%$ nitroglycerin could prevent the zone of stasis and could be a new agent in clinical use.

\section{MATERIALS AND METHODS}

The study protocol was approved by the Selçuk University Medical Faculty Ethics Committee (2015/85-29/09/20I5) and founded by the Selçuk University Research Projects Fund Committee (16401032-07/10/2015). Thirty Wistar-Albino rats, each weighing 250-300 grams, were used. They were caged in a controlled environment of $22{ }^{\circ} \mathrm{C}$ with 12 hours of light and dark cycles. Standard rat laboratory feed and water were provided. All animals in the present study received humane care in compliance with the Guide for the Care and Use of Laboratory Animals published by the Ethics Council.

General anesthesia was induced with intraperitoneal ketamine $500 \mathrm{mg}$ (Ketalar $500 \mathrm{mg}$ Pfizer) at $50 \mathrm{mg} / \mathrm{kg}$ and $2 \%$ xylazine (Xylazinbo 2\% Bioveta). The entire backs of the rats were shaved, and the procedure for creating a "comb burn" model, which was deemed to be the most appropriate experimental model to produce an injury with predictable zones and was first described by Regas and Erhlich, was used. ${ }^{[8]}$ In this model, a probe, consisting of four rows $(10 \mathrm{~mm} \times 20$ $\mathrm{mm}$ ) and three interspaces $(5 \mathrm{~mm} \times 20 \mathrm{~mm})$, was immersed in boiling water for five minutes for thermal equilibrium and was held for 20 seconds without applying pressure on the back of the rat $5 \mathrm{~mm}$ lateral to the midline (Fig. Ia). By this model, we also tried to protect the agent itself from disappearing, oozing away using touching around and licking. They were divided randomly into five groups with six rats in each group (control, Vaseline-lanolin (sham), bacitracin-neomycin sulfate, $2 \%$ nitroglycerin, and silver sulfadiazine $1 \%$, respectively). Topical agents containing $2 \%$ nitroglycerin, $1 \%$ silver sulfadiazine, bacitracin-neomycin sulfate, and Vaseline-lanolin (sham) were applied until covering the surface of the burn area, including the zone of stasis, after creating a burn model in 0,24 , and 48 hours we did not use overlying dressing. One rat died in Group 3 (bacitracin-neomycin sulfate) 48 hours later. After 72 hours, the rats were sacrificed under general anesthesia; then biopsies were performed from the zone of stasis (Fig. Ib) and evaluated by histomorphological (edema, congestion, inflammation, and vascular proliferation) and immunohistochemical CD 34 (expressed in human endothelial and hematopoietic cells) and D 2-40 (expressed in the endothelium of lymphatic capillaries) methods. Histomorphological and immunohistochemical analyses were performed in all cases on formalin-fixed, paraffin-embedded tissues. Serial sections $(4 \mu)$ from the zone of stasis were cut and used for hematoxylin-eosin and immunohistochemistry. An immunohistochemistry technique following the protocol was used to characterize the CD 34 and D 2-40 tissue activity in the cells according to the manufacturer's instructions. CD 34 (Anti-Human CD34 Monoclonal Antibody [Endothelial Cell], BioGenex, the Netherlands) staining is specifically used to evaluate the number of vessels and vascularization. D 2-40 (FLEX Monoclonal Mouse Anti-Human Podoplanin Clone D2-40, Dako, Denmark) is expressed in the endothelium of lymphatic capillaries. A Carl Zeiss AXIO imager Al microscope was used, and the pathologist was blinded. Brown-colored staining was considered a positive in both for CD 34 and D 2-40 antibodies. All parameters were graded based on the scale of absent:0, weakly positive:I, moderate:2, and strongly positive:3, retrospectively as Kayapınar et al., ${ }^{[9]}$ Kukreja et al., ${ }^{[10]}$ and Salzman et al. ${ }^{[1]}$ described. The results were evaluated using the chi-square test. We used the statistical software package SPSS version 19.0 for statistical analyses. A p-value of $<0.05$ was considered statistically significant.

\section{RESULTS}

Histological parameters in hematoxylin-eosin stained tissues included edema, congestion, inflammation, and vascular proliferation. Comparing in all groups group (control, Vaselinelanolin (negative control-sham), bacitracin-neomycin sulfate, $2 \%$ nitroglycerin, and silver sulfadiazine $\% \mathrm{l}$ ) in the zone of
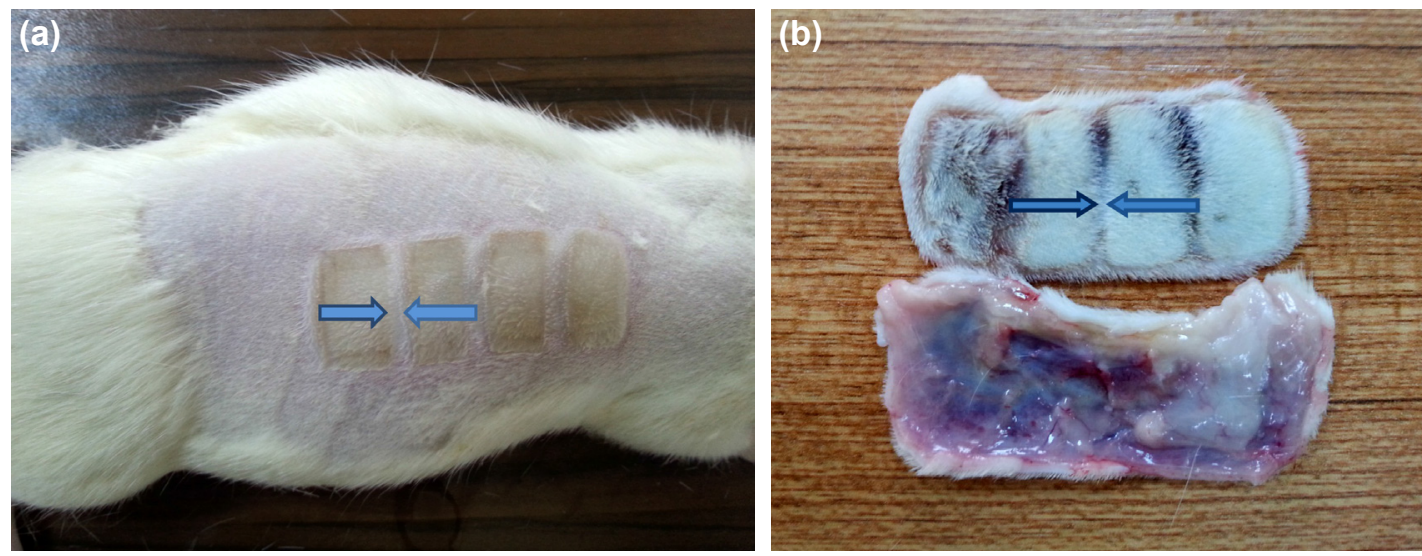

Figure 1. "Comb burn" model was created, the zone of stasis is seen. (a) The zone of stasis. (b) The zone of stasis biopsies taken from. 

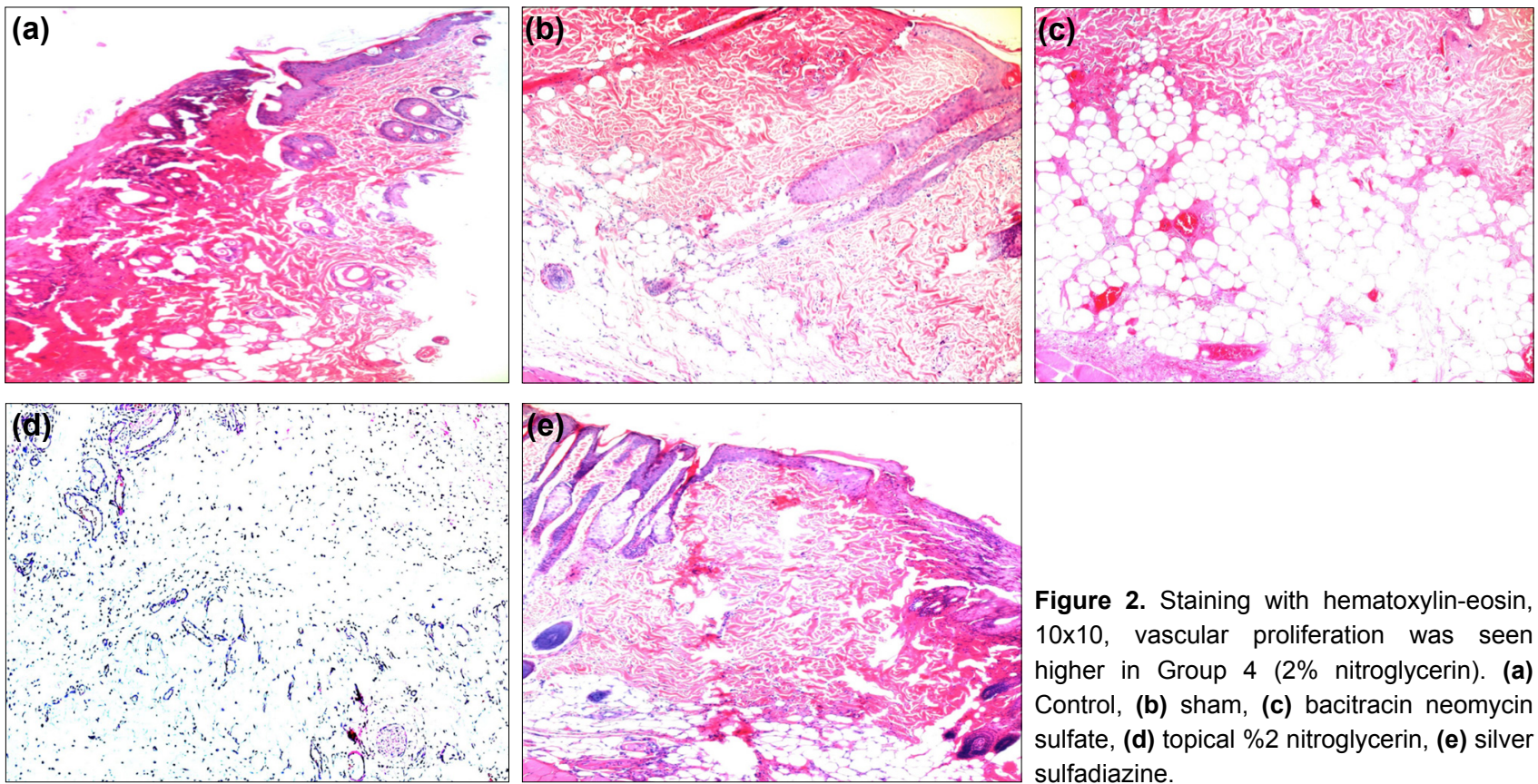

Figure 2. Staining with hematoxylin-eosin, $10 \times 10$, vascular proliferation was seen higher in Group 4 (2\% nitroglycerin). (a) Control, (b) sham, (c) bacitracin neomycin sulfate, (d) topical \%2 nitroglycerin, (e) silver

stasis, vascular proliferation was determined to be significantly higher in Group 4 ( $2 \%$ nitroglycerin) $(p<0.05)$ (Fig. 2). Inflammation was seen in all groups, but in Group 4 (2\% ni- troglycerin), it was strongly positive $(p<0.05)$. Edema was also significantly higher in Group 4 ( $2 \%$ nitroglycerin) (Table I). No difference was found in congestion.

Table I. Histomorphologic evaluation and scoring system

\begin{tabular}{|c|c|c|c|c|c|c|}
\hline & $\begin{array}{c}\text { Group I } \\
(n=6)\end{array}$ & $\begin{array}{c}\text { Group } 2 \\
(n=6)\end{array}$ & $\begin{array}{c}\text { Group } 3 \\
(n=5)\end{array}$ & $\begin{array}{c}\text { Group } 4 \\
(n=6)\end{array}$ & $\begin{array}{c}\text { Group } 5 \\
(n=6)\end{array}$ & $\mathbf{p}$ \\
\hline \multicolumn{7}{|l|}{ Edema } \\
\hline Absent & 4 & 3 & 2 & 0 & 0 & 0.002 \\
\hline Weakly positive & 2 & 3 & 3 & 0 & 3 & \\
\hline Moderate & 0 & 0 & 0 & 1 & 3 & \\
\hline Strongly positive & 0 & 0 & 0 & 5 & 0 & \\
\hline \multicolumn{7}{|l|}{ Congestion } \\
\hline Absent & 2 & 0 & I & 0 & 0 & 0.121 \\
\hline Weakly positive & 4 & 5 & 2 & 2 & 5 & \\
\hline Moderate & 0 & I & 2 & 2 & 1 & \\
\hline Strongly positive & 0 & 0 & 0 & 2 & 0 & \\
\hline \multicolumn{7}{|l|}{ Inflammation } \\
\hline Absent & 4 & $\mathrm{I}$ & I & 0 & 1 & 0.004 \\
\hline Weakly positive & 2 & 4 & 2 & 0 & 5 & \\
\hline Moderate & 0 & 1 & 2 & 3 & 0 & \\
\hline Strongly positive & 0 & 0 & 0 & 3 & 0 & \\
\hline \multicolumn{7}{|l|}{ Vascular proliferation } \\
\hline Absent & 5 & 3 & 0 & 0 & 1 & 0.001 \\
\hline Weakly positive & 1 & 0 & 2 & 0 & 5 & \\
\hline Moderate & 0 & 3 & 2 & I & 0 & \\
\hline Strongly positive & 0 & 0 & I & 5 & 0 & \\
\hline
\end{tabular}

$\mathrm{n}$ : Number of biopsies taken from each rat. Absent, weakly positive, moderate, and strongly positive were graded as $0,1,2$, and 3 retrospectively. 

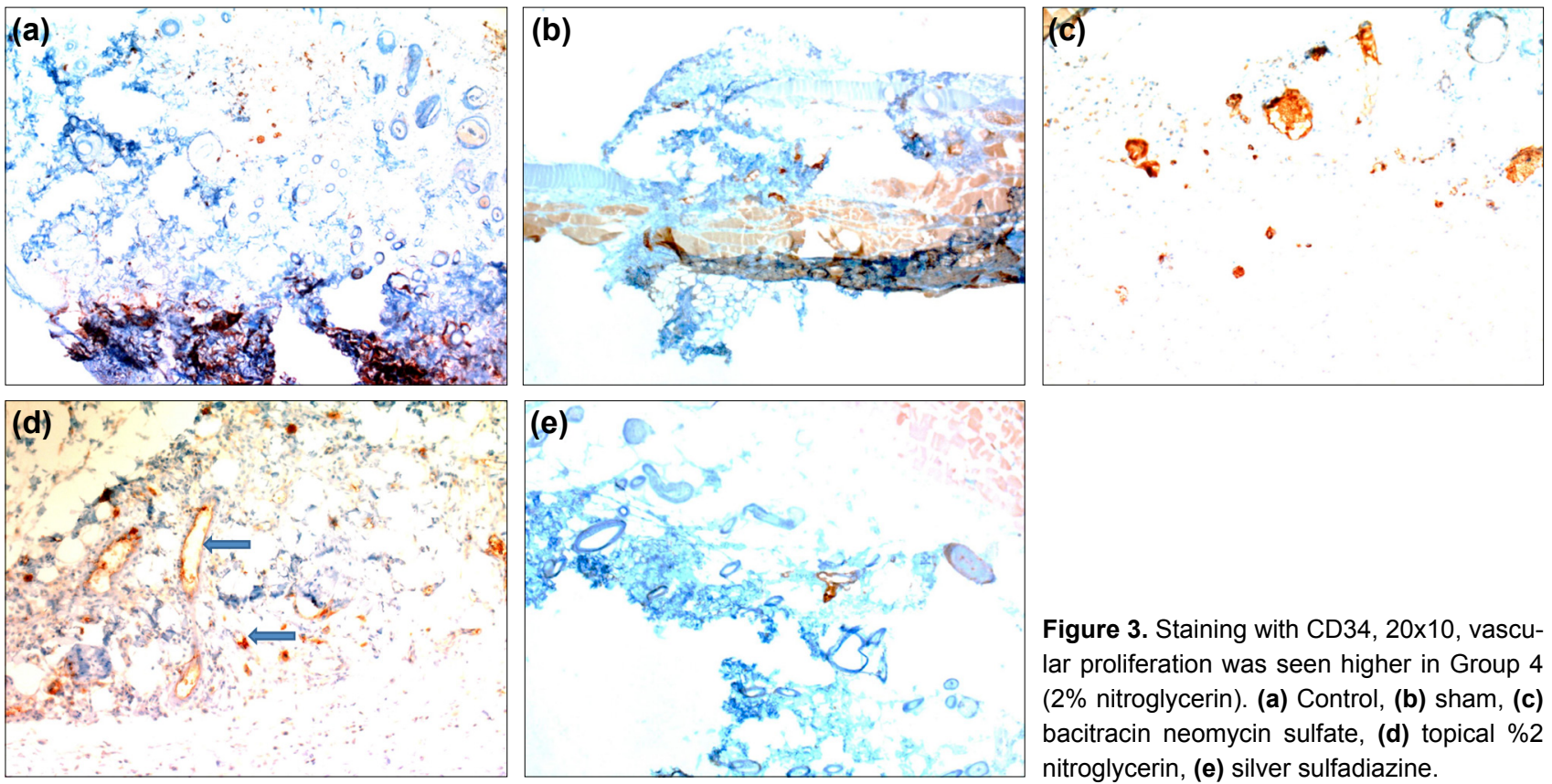

Figure 3. Staining with CD34, 20x10, vascular proliferation was seen higher in Group 4 (2\% nitroglycerin). (a) Control, (b) sham, (c) bacitracin neomycin sulfate, (d) topical $\% 2$ nitroglycerin, (e) silver sulfadiazine.

In immunohistochemical evaluation compared with other groups, staining with CD 34 was strongly positive in Group 4 ( $2 \%$ nitroglycerin) $(p<0.05)$ (Fig. 3). Comparing with other groups, D 2-40 staining was also significantly higher in Group 4 (2\% nitroglycerin) $(p<0.05)$ (Fig. 4, Table 2$)$.

\section{DISCUSSION}

Recovery in the zone of stasis is possible due to preventing necrosis in burned tissue. ${ }^{[2]}$ Inflammatory reaction, the proliferative process, and tissue remodeling are the basic parts of acute wound healing. The reconstitution of the dermis includes new blood vessel formation and angiogenesis that involves a phenotypic alteration of endothelial cells. ${ }^{[13]}$ Several studies were performed to evaluate the zone of stasis. In an experimental study, intraperitoneal and oral $\mathrm{N}$-acetylcysteine (NAC) administration were used in treatment groups, and the possible saving the effect of NAC on the zone of stasis was shown. ${ }^{[14]}$ Wang et al. ${ }^{[15]}$ studied oxidative stress in the comb burn model. They applied a lotion that consists of two components EDTA disodium as the active, chelating agent and methyl sulfonyl methane as a permeation enhancer every eight hours for three days. Burn progression was protected by this lotion in their report. Different from the present study, they evaluated an antioxidant agent's effect.
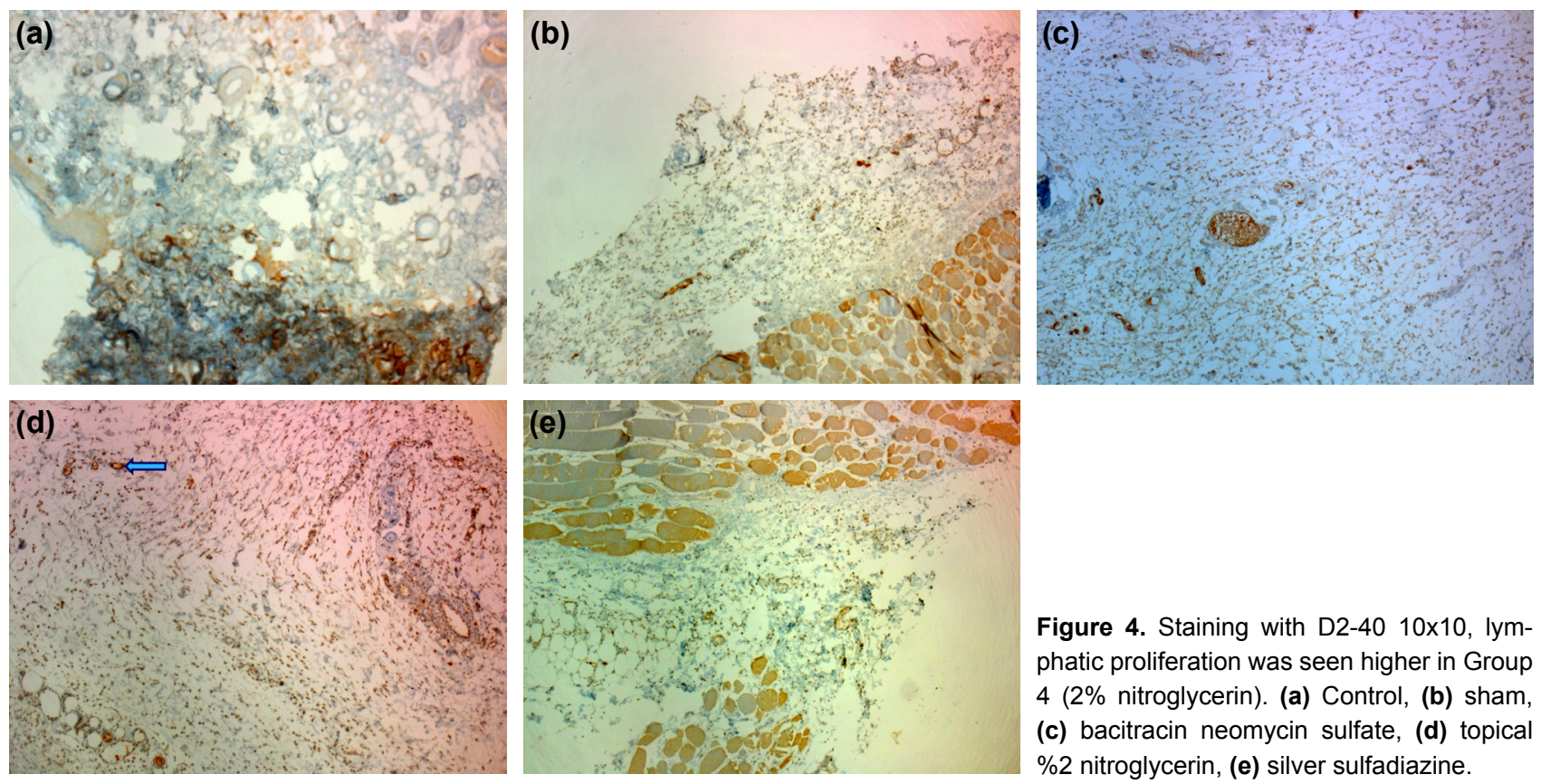

Figure 4. Staining with D2-40 10x10, lymphatic proliferation was seen higher in Group 4 (2\% nitroglycerin). (a) Control, (b) sham, (c) bacitracin neomycin sulfate, (d) topical $\% 2$ nitroglycerin, (e) silver sulfadiazine. 
Table 2. Immunohistochemical evaluation and scoring system

\begin{tabular}{|c|c|c|c|c|c|c|}
\hline & $\begin{array}{c}\text { Group I } \\
(n=6)\end{array}$ & $\begin{array}{c}\text { Group } 2 \\
(n=6)\end{array}$ & $\begin{array}{c}\text { Group } 3 \\
(n=5)\end{array}$ & $\begin{array}{c}\text { Group } 4 \\
(n=6)\end{array}$ & $\begin{array}{c}\text { Group } 5 \\
(n=6)\end{array}$ & $\mathbf{p}$ \\
\hline \multicolumn{7}{|l|}{ CD34 } \\
\hline Absent & 1 & 5 & 0 & 0 & 0 & 0.001 \\
\hline Weakly positive & 5 & 0 & 2 & 0 & 6 & \\
\hline Moderate & 0 & 1 & 1 & 0 & 0 & \\
\hline Strongly positive & 0 & 0 & 2 & 6 & 0 & \\
\hline \multicolumn{7}{|l|}{ D2-40 } \\
\hline Absent & 3 & I & 0 & 0 & I & 0.002 \\
\hline Weakly positive & 3 & 3 & 1 & 0 & 4 & \\
\hline Moderate & 0 & 2 & 0 & 0 & 0 & \\
\hline Strongly positive & 0 & 0 & 4 & 6 & I & \\
\hline
\end{tabular}

$\mathrm{n}$ : Number of biopsies taken from each rat. Absent, weakly positive, moderate, and strongly positive were graded as $0,1,2$, and 3 retrospectively.

The physiologic anticoagulant activated protein $\mathrm{C}$ was administered intravenously after two hours of burn induction in a rat model. Blood-flow measurements with laser Doppler flowmetry in the activated protein $\mathrm{C}$-treated group were shown to be significantly higher on the third-day post-burn in their study. ${ }^{[2]}$ Similar to the present study, activated protein $\mathrm{C}$ improved the perfusion of the zone of stasis but in a different mechanism.

Türkaslan et al. ${ }^{[16]}$ reported the effects of hyperbaric oxygen treatment in recovering the zone of stasis. Hyperbaric oxygen treatments were administered at 2.5 atmospheres for 90 minutes twice a day for one day on the first day in the first group and five days in the second group. According to their results, hyperbaric oxygen treatment stops the progression of the zone of stasis in necrosis in the first 24 hours. Our results also support neo-angiogenesis.

The effects of a topical antiseptic agent, cerium nitrate, which also reduce the alarm cytokine levels, macromolecular leakage, and decreases leukocyte activation, were evaluated in the zone of stasis following the burn. Rats were kept in basins filled with $0.09 \%$ saline and cerium nitrate for the control and treatment groups, respectively. They reported the prevention of progressive tissue necrosis in the zone of stasis by cerium nitrate bathing. The viability of the zone of stasis was assessed with 99-m Tc-sestamibi scintigraphy. ${ }^{[17]}$

Kayapınar et al. ${ }^{[9]}$ injected melatonin intraperitoneally for seven days after creating a burn comb model in rats. Due to its antioxidant effect, melatonin showed favorable results in saving the zone of stasis in their study. A different mechanism was observed in our study to prevent the stasis zone.

Firat et al. ${ }^{[18]}$ applied $\beta$-glucan, which has immunomodulatory and antioxidant effects, to the zone of stasis and pointed to its efficacy. They compared treatment with $\beta$-glucan \pm topical pomade with no treatment and topical treatment alone (bacitracin-neomycin sulphate) in the comb burn model. Severe inflammation and edema were also seen. The vasodilator effect of $2 \%$ nitroglycerin may have increased edema and inflammation in our study.

Treatment with recombinant tissue-type plasminogen activator in rats also demonstrated the benefits of saving the zone of stasis in burns. ${ }^{\left[{ }^{19]}\right.}$ Results were due to its fibrinolytic effects, which constituted a different way of protecting the stasis zone.

Topical nitroglycerin is being used in the treatment of anal fissures and is recommended as an alternative treatment option to surgery. ${ }^{[20]}$ Differently, to prevent tissue necrosis in the zone of stasis, we hypothesized that a topical agent containing $2 \%$ nitroglycerin should decrease it by affecting a vascular response and improve blood supply. Several studies reported the effects of nitroglycerin in the dermal vasculature.

For evaluation of early post-burn ischemic necrosis of the skin, Tagkalakis et al. ${ }^{[2]}$ investigated the effects of $0.4 \%$ nitroglycerin ointment in comparatively to no application and placebo in an experimental study. Experimental burn model, evaluation with laser Doppler at 15, 30, 45, 60, 120 and 180 minutes after preparation application, and percentage of nitroglycerin ointment were the differences. As in the present study, the use of $0,4 \%$ nitroglycerin ointment improved perfusion. ${ }^{[21]}$

Gorman et al. ${ }^{[22]}$ compared topical nitroglycerin and flurbiprofen in the rat comb model. Differently from the present study, they had four rats each in the $5 \%$ flurbiprofen group and $2 \%$ nitroglycerin group. Also, they excised specimens after 24 hours. The $2 \%$ nitroglycerin-treated rats demonstrated full 
patency of the interspatial dermal blood vessels. We showed significant vascular proliferation in the $2 \%$ nitroglycerin group. Additionally, three days of the treatment may provide greater clinical effects.

Yregård et al. ${ }^{[23]}$ investigated the effects of topical local anaesthetics on the inflammatory cascade of a burn wound in vivo. They covered the experimental burn area with lidocaine/ prilocaine cream and evaluation was performed after two hours. Improved circulation in the postburn area was shown due to the inhibitory effects of the local anesthetic cream on thromboxane release.

Supporting our results, Kleydman et al. ${ }^{[7]}$ mentioned the improvement of flow in the dermal vasculature after soft tissue augmentation by the use of a nitroglycerin paste.

Davis et al. ${ }^{[24]}$ compared topical anti-ischemic agents in the salvage of failing random-pattern skin flaps in rats. They used nifedipine, trolamine-salicylate, nitroglycerin, a trolamine-salicylate nitroglycerin combination, and a nifedipine trolaminesalicylate nitroglycerin combination as topical agents. They suggested that these anti-ischemic agents are effective in reducing the ischemic necrosis of failing, random-pattern skin flaps. Although the experimental model was different, the main effect and results of these agents were similar to our hypothesis and results.

In an experimental study, botulinum toxin $A$ and nitroglycerin increased flap viability on random skin flaps. ${ }^{[25]}$ Topical nitroglycerin was also used in the management of tissue ischemia in mastectomy skin flaps, and as in our study, improvement in perfusion was shown but differently by angiography. ${ }^{[26]}$

We aimed to limit the progression of necrosis and to salvage the zone of stasis. Prevention from infection is an important factor in burn recovery. ${ }^{[5]}$ Additionally, as mentioned above, there are many agents for salvaging the zone of stasis in the burn as antioxidants, immunomodulators, anticoagulants, anti-inflammatories, fibrinolytics, and hyperbaric oxygen treatment. Inflammation, reepithelialization, fibroplasia, and angiogenesis are the processes of wound healing. ${ }^{[13]}$ The topical containing $2 \%$ nitroglycerin in the present study can be applied easily. By a different route, vascular and lymphatic proliferation due to $2 \%$ nitroglycerin was shown in our study. Improving the blood supply in the stasis zone reduces necrosis. Different from other agents, such as melatonin, recombinant tissue-type plasminogen activator, topical 2\% nitroglycerin can be applied easily. Also, further studies evaluating the effects of topical $2 \%$ nitroglycerin at later times as days 10 and 14 may enlarge and support our hypothesis. While generalizing the comb burn model to human burns, the effects of probe rows are similar to body surface that directly contacts with burn agent. Also, interspaces of the probe are similar to the surrounding area of the contacted body. The effects of many agents in different mechanisms like topically applied metal chelators, ${ }^{[15]} \beta$-glucan ${ }^{[18]}$ were used in the comb burn model. Those agents are not being used in humans. Although topical nitroglycerin has a similar limitation in burns and needs further studies, it can be used in anal fissure treatment in humans. ${ }^{[20]}$ Another limitation is the side effects like headache, dizziness, faintness, and various allergic reactions, such as itching; swelling of the lips, throat, or tongue; and difficulty in breathing are the side effects of topical $2 \%$ nitroglycerin. ${ }^{[27]}$ Different from the present study, results may differ in studies, including overlying dressing.

\section{Conclusion}

This study demonstrated the increase of vascular proliferation due to topical $2 \%$ nitroglycerin in the zone of stasis in the burn, which could possibly affect recovery and should be studied in future clinical trials.

Funding: This study was funded by the Selçuk University Research Projects Fund Committee (16401032-07//0/2015).

Ethics Committee Approval: This study protocol was approved by the Selçuk University Medical Faculty Ethics Committee (2015/85-29/09/2015).

Peer-review: Internally peer-reviewed.

Authorship Contributions: Concept: M.G., I.Ç.; Design: M.G., T.S., C.U., I.Ç.; Supervision: M.G.; Fundings: M.G., T.S., C.U., I.Ç.; Materials: M.G., T.S., C.U.; Data: M.G., C.U.; Analysis: M.G., C.U., I.Ç.; Literature search: M.G.; Writing: M.G.; Critical revision: M.G., I..Ç.

Conflict of Interest: None declared.

Financial Disclosure: Selçuk University Research Projects Fund Committee (16401032-07//0/2015).

\section{REFERENCES}

1. Jackson DM. The Diagnosis of the Depth of Burning. Br J Surg 1953;40:588-96. [CrossRef]

2. Pham TN, Gibran NS, Heimbach DM. Evaluation of the burn wound: management decisions. In: Herndon DN, editor. Total Burn Care. 3rd ed. Philadelphia: Saunders; 2017.p:119-26. [CrossRef]

3. Choi M, Ehrlich HP. U75412E, a lazaroid, prevents progressive burn ischemia in a rat burn model. Am J Pathol 1993;142:519-28.

4. Zawacki BE. Reversal of capillary stasis and prevention of necrosis in burns. Ann Surg 1974;180:98-102. [CrossRef]

5. Murphy KD, Lee JO, Herndon DN. Current pharmacotherapy for the treatment of severe burns. Expert Opin Pharmacother 2003;4:369-84.

6. Schonberger RB, Worden WS, Shahmohammadi K, Menn K, Silverman TJ, Stout RG, et al. Topical non-iontophoretic application of acetylcholine and nitroglycerin via a translucent patch: a new means for assessing microvascular reactivity. Yale J Biol Med 2006;79:1-7.

7. Kleydman K, Cohen JL, Marmur E. Nitroglycerin: a review of its use in the treatment of vascular occlusion after soft tissue augmentation. Dermatol Surg 2012;38:1889-97. [CrossRef]

8. Regas FC, Ehrlich HP. Elucidating the vascular response to burns with a new rat model.J Trauma 1992;32:557-63. [CrossRef]

9. Kayapınar M, Seyhan N, Avunduk MC, Savacı N. Saving the zone of sta- 
sis in burns with melatonin: an experimental study in rats. Ulus Travma Acil Cerrahi Derg 2015;21:419-24. [CrossRef]

10. Kukreja I, Kapoor P, Deshmukh R, Kulkarni V. VEGF and CD 34: A correlation between tumor angiogenesis and microvessel density-an immunohistochemical study. J Oral Maxillofac Pathol 2013;17:367-73.

11. Salzman R, Stárek I, Kučerová L, Skálová A, Hoza J. Neither expression of VEGF-C/D nor lymph vessel density supports lymphatic invasion as the mechanism responsible for local spread of recurrent salivary pleomorphic adenoma. Virchows Arch 2014;464:29-34. [CrossRef]

12. Nisanci M, Eski M, Sahin I, Ilgan S, Isik S. Saving the zone of stasis in burns with activated protein C: an experimental study in rats. Burns 2010;36:397-402. [CrossRef]

13. Li J, Chen J, Kirsner R. Pathophysiology of acute wound healing. Clin Dermatol 2007;25:9-18. [CrossRef]

14. Deniz M, Borman H, Seyhan T, Haberal M. An effective antioxidant drug on prevention of the necrosis of zone of stasis: $\mathrm{N}$-acetylcysteine. Burns 2013;39:320-5. [CrossRef]

15. Wang CZ, Ayadi AE, Goswamy J, Finnerty CC, Mifflin R, Sousse L, et al. Topically applied metal chelator reduces thermal injury progression in a rat model of brass comb burn. Burns 2015;41:1775-87. [CrossRef]

16. Türkaslan T, Yogun N, Cimşit M, Solakoglu S, Ozdemir C, Ozsoy Z. Is HBOT treatment effective in recovering zone of stasis? An experimental immunohistochemical study. Burns 2010;36:539-44. [CrossRef]

17. Eski M, Ozer F, Firat C, Alhan D, Arslan N, Senturk T, et al. Cerium nitrate treatment prevents progressive tissue necrosis in the zone of stasis following burn. Burns 2012;38:283-9. [CrossRef]

18. Firat C, Samdanci E, Erbatur S, Aytekin AH, Ak M, Turtay MG, et al. $\beta$-Glucan treatment prevents progressive burn ischaemia in the zone of stasis and improves burn healing: an experimental study in rats. Burns
2013;39:105-12. [CrossRef]

19. Işik S, Sahin U, Ilgan S, Güler M, Günalp B, Selmanpakoğlu N. Saving the zone of stasis in burns with recombinant tissue-type plasminogen activator ( $\mathrm{r}-\mathrm{tPA}$ ): an experimental study in rats. Burns 1998;24:217-23.

20. Ehrenpreis ED, Rubin DT, Ginsburg PM, Meyers JS. Treatment of anal fissures with topical nitroglycerin. Expert Opin Pharmacother 2001;2:41-5. [CrossRef]

21. Tagkalakis P, Dionyssopoulos A, Karkavelas G, Demiri E. Topical use of Rectogesic ${ }^{\oplus}$ and Emla ${ }^{\oplus}$ to improve cutaneous blood perfusion following thermal injury. A comparative experimental study. Ann Burns Fire Disasters 2015;28:134-41.

22. Gorman PJ, Saggers G, Ehrlich P, Mackay DR, Graham WP 3rd. Effects of topical nitroglycerin and flurbiprofen in the rat comb burn model. Ann Plast Surg 1999;42:529-32. [CrossRef]

23. Yregård L, Cassuto J, Tarnow P, Nilsson U. Influence of local anaesthetics on inflammatory activity postburn. Burns 2003;29:335-41. [CrossRef]

24. Davis RE, Wachholz JH, Jassir D, Perlyn CA, Agrama MH. Comparison of topical anti-ischemic agents in the salvage of failing random-pattern skin flaps in rats. Arch Facial Plast Surg 1999;1:27-32. [CrossRef]

25. Ghanbarzadeh K, Tabatabaie OR, Salehifar E, Amanlou M, Khorasani G. Effect of botulinum toxin A and nitroglycerin on random skin flap survival in rats. Plast Surg (Oakv) 2016;24:99-102. [CrossRef]

26. Sanniec K, Teotia S, Amirlak B. Management of Tissue Ischemia in Mastectomy Skin Flaps: Algorithm Integrating SPY Angiography and Topical Nitroglycerin. Plast Reconstr Surg Glob Open 2016;4:e1075. [CrossRef]

27. Salari M, Salari R, Dadgarmoghadam M, Khadem-Rezaiyan M, Hosseini M. Efficacy of egg yolk and nitroglycerin ointment as treatments for acute anal fissures: A randomized clinical trial study. Electron Physician 2016;8:3035-41. [CrossRef]

\section{DENEYSEL ÇALIŞMA - ÖZET}

\section{Sıçanlarda deneysel yanık modelinde oluşan staz zonunda nitrogliserinin etkisi}

\section{Dr. Metin Gündüz,, Dr. Tamer Sekmenli, ${ }^{1}$ Dr. Ceyhan Uğurluoğlu, ${ }^{2}$ Dr. İlhan Çiftçi'}

${ }^{1}$ Selçuk Üniversitesi Tıp Fakültesi, Çocuk Cerrahisi Anabilim Dalı, Konya

${ }^{2}$ Selçuk Üniversitesi Tıp Fakültesi, Patoloji Anabilim Dalı, Konya

AMAÇ: Yanıkta direkt termal etkiyle doku ölümü dışında dermal vasküler oklüzyon ve akut tromboz görülür. Jackson tarafından termal yanığın başlangııında ortaya çıkan koagülasyon, staz ve hiperemi zonlarında oluşan yanık modeli tariflenmiştir. Bu çalışmada antiiskemik ve vazodilatör etkinliği olan \%2 nitrogliserin staz bölgesine uygulanarak rutin tedavide kullanılan gümüş sulfadiyazin \% I krem ve basitrasin-neomisin pomad ile karşılaştırılarak yanık tedavisinde etkinliği ve kullanılabilirliğinin histomorfolojik ve immünhistokimyasal olarak değerlendirilmesi amaçlandı.

GEREÇ VE YÖNTEM: Çalışmamızda beş gruptan oluşan 30 adet sıçan kullanıldı. Grup I; kontrol, 2; sham, 3; basitrasin-neomisin sülfat, 4; \%2 nitrogliserin ve 5; gümüş sülfadiazin \% l olarak oluşturuldu. 'Comb' yöntemiyle yanık oluşturulup 0, 24 ve 48. saatlerde bu bölgelere lokal olarak vazelin-lanolin, basitrasin-neomisin sülfat, \%2 nitrogliserin ve gümüş sülfadiazin \%। uygulanıp 72. saate patolojik değerlendirme için biyopsi alındı. Alınan materyaller uygun şekilde saklanıp histomorfolojik ve CD 34 ve D 2-40 immün boyaları ile boyanarak vasküler ve lenfatik yapılar immünohistokimyasal olarak değerlendirildi.

BULGULAR: Histopatolojik incelemelerde \%2 nitrogliserin uygulanan grupta diğer gruplarla karşılaştırıldı̆̆ında ödem, enflamasyon ve vasküler proliferasyonda istatistiksel olarak anlamlı artış saptandı.

TARTIŞMA: İskemik olan staz zonunda topikal \%2 nitrogliserinin vasküler proliferasyonu artırdığı gözlenmiş olup yanık tedavisinde etkinliğinin olabileceği gösterilmiştir.

Anahtar sözcükler: Nitrogliserin; staz zonu; yanık.

Ulus Travma Acil Cerrahi Derg 2020;26(2):171-177 doi: 10.14744/tjtes.2019.00005 